\title{
FUNCTIONAL AND TECHNOLOGICAL CHARACTERISTICS OF NEW CHEESE PRODUCT WITH VEGETABLE AND PREBIOTIC COMPONENTS
}

\author{
Marina Slozhenkina $^{1,2}$, Olga Serova $^{2}$, Margarita Vodolazkova ${ }^{2}$, Elena Zlobina ${ }^{1,3}$ \\ ${ }^{1}$ Volga Region Research Institute of Manufacture and Processing of Meat-And-Milk Production, \\ Russia; ${ }^{2}$ Volgograd State Technical University, Russia; ${ }^{3}$ Volgograd State University, Russia \\ slozhenkina@mail.ru,tpp@vstu.ru, vodolazkova.margo@yandex.ru, elenazlobina2008@yandex.ru
}

\begin{abstract}
The article presents results of a study of a new cheese product, the manufacturing technology of which involves enrichment with natural vegetable raw material in combination with prebiotic components. The proposed production technology enables to improve the content of protein, selenium, and mass fraction of dry matter in the final product. Extruded chickpea flour was used as a plant component. Chickpea grain has a high content of protein and carbohydrates with low content of fat. The extrusion process makes it possible to eliminate a specific flavor characteristic for the legumes and improve the organoleptic and rheological characteristics of the product. The extrusion was carried out at a temperature of $120^{\circ} \mathrm{C}$ and a pressure of $70 \mathrm{~atm}$. that enabled to reduce the content of trypsin inhibitors, increase the digestibility of nutrients, and get a filler with a pleasant flavour of "popcorn". The combination of chickpea flour and lactulose contributes to enhancing the content of lactic acid microorganisms in a cheese product, causing its functional activity in case of a microflora imbalance in the gastrointestinal tract. The weight fractions of protein in the test samples with adding of chickpea flour were higher by $5.2 \%$ compared to the control sample. $3 \%$ chick-pea flour added increased the weight fraction of selenium by $10.1 \mathrm{mcg}$, while $6 \%$ chick-pea flour by $22.5 \mathrm{mcg}$ per $100 \mathrm{~g}$ of the product. Adding of lactulose increased the fermentation process. So, in 3 hours of fermentation of the mixture in the $1.5 \%$ lactulose sample, the titratable acidity was by $12 \%$ and in the $3 \%$ lactulose sample by $21 \%$ higher than in the control sample. At the same time, due to the reduced content of fat it was considered a dietary low-caloric product. Thus, adding of extruded chick-pea flour to the formulation of the cheese product contributes to the improvement of consumer-oriented characteristics and the combination with the lactulose prebiotics causes its functional properties.
\end{abstract}

Keywords: cheese product, cryo-concentration, extruded chickpea flour, lactulose, functional food.

\section{Introduction}

The most important strategic objective of the food industry is to meet the needs of all categories of the population in high-quality, biologically adequate, and safe food [1-3]. Among the wide variety food cheese is of great importance. The world nutritional science considers cheese as a highly and easily digestible product [4]. The modern market, however, has a wide range of cheese, which contains synthetic food additives: preservatives, colorings, and flavorings used to improve the flavor, slow spoilage and prolong the shelf life [5]. Some studies proved that a number of synthetic food additives, depending on the individual effects, are able to adversely affect the health and accumulate in the liver in case of constant consuming. An important direction of the food industry, including the dairy industry, is the exception of synthetic additives from the formulations and the use of natural extracts of plant and animal origin that contain vital biologically active substances [6-8].

The minimum consumption or absence of biologically active substances in the diet is one of the reasons for the low level of health and shorter life expectancy. Enrichment of food is the most effective way to solve the problem of deficiency of protein, minerals, vitamins, etc. Dietary protein deficiency is not only an economic but also a social problem of the modern world. Not in all countries the products of animal origin are available to the broad layers of population. In the areas of SubSaharan Africa, tropic Latin America and Asia, where the population is involved in heavy agricultural labor, the problem of animal protein is particularly acute. Among the most common protein sources, chickpeas, containing the complementary protein, essential fatty acids, vitamins, minerals, and other dietary nutrients, deserve special attention. In recent years, there has been a growing interest in processing vegetable raw materials by extrusion that is an environmentally friendly, resource-saving and versatile process, which makes it possible to produce highly digestible thermo-sterilized foods with improved nutritional value, better structural and functional properties and organoleptic characteristics [9]. In extrusion, various aromatic substances are formed, the activity of enzymes increases, toxins get neutralized and their producers die.

Dysbacteriosis is the most common disease of the population in our planet and is detected in $90 \%$ of adults and $95 \%$ of children. This statistics is caused by many reasons and the ease of dysbiosis to 
be caught. In our time of stress, bad environmental and diet disorder it is very difficult to save the intestinal flora in a normal condition [10]. The abrupt change of the nutrition type, tobacco, alcohol and infections have a direct or indirect impact on the gastrointestinal tract and thereby its pool of microorganisms. Lactulose is a prebiotic, which is not split by enzymes of the gastrointestinal tract (GIT) and is not absorbed, transits the upper GIT and unchanged reaches the colon, where selectively stimulates the growth and vital activity of bifidobacteria and lactobacilli and inhibits the pathogens. In Russia, the lactulose preparation is available under the trademark "Laktusan" (ZAO "Felitsata", Moscow, Russia), which is a non-crystallizable syrup with a dry matter content of at least $55 \%$, including lactulose of at least $35 \%$.

In connection with the above, the authors have developed a formulation of a new cheese product with high-protein vegetable raw material, which is not only able to enrich the finished product with a complex of biologically active substances, but also possesses stabilizing properties and is a flavoring agent; in combination with a probiotic component it has a preventive effect against some physiological conditions caused by dysfunctioning of the GIT.

The purpose of the experimental study was to evaluate the effect of the vegetable and prebiotic components on the energy and nutritional value, consumer properties, and quality profile of the food produced.

\section{Materials and Methods}

Milk and plant raw materials and lactulose were used to develop a pilot batch. Extruded chickpea flour was used as the plant raw material.

\section{Preparation of the plant component}

The chickpea grain (Fig. 1.1) was treated in an extruder press at a pressure of up to 70 atmospheres and a temperatures of up to $120^{\circ} \mathrm{C}$ for $8-10 \mathrm{sec}$., yielding an expanded and porous strand product with a diameter of $10-15 \mathrm{~mm}$, a bulk weight of $100-120 \mathrm{~g} \cdot \mathrm{dm}^{-3}$ and a moisture content of 7-9\% with a pleasant taste and flavor (Fig. 1.2). Grinding of the raw material was carried out on rollers with a grooved or micro-rough surface in accordance with the rules of organizing and conducting the process in the flour mills; other related equipment may also be used. After milling, the flour was sifted through a silk sieve of no. 35. The fine flour yield was at least $60 \%$.

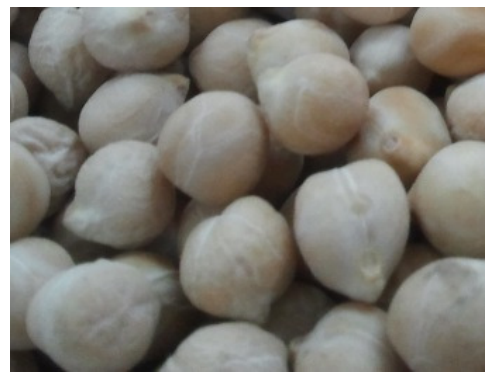

1

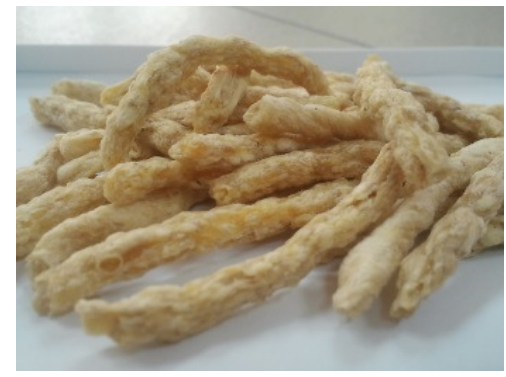

2

Fig. 1. Plant component: 1 - chickpea grain; 2 - extrudate

\section{Production technology of the cheese product}

The flow sheet of the cheese product is shown in Fig. 2. The technology features are the long preliminary heat treatment of milk at a temperature of $90-95^{\circ} \mathrm{C}$; ageing for three hours until the product had specific organoleptic characteristics typical for baked milk; the removal of whey from protein coagulum by means of cryo-concentration; and the addition of vegetable and prebiotic components. Currently, the basic techniques of removing moisture from foods are evaporation, membrane separation techniques (hyperfiltration and electrodialysis) and cryo-concentration. The main advantage of the latter is a high degree of preserving high quality of the product, since the whole process goes at low temperatures. It especially concerns the conservation of aromatic substances and vitamins. Furthermore, cryo-concentration is more cost effective in comparison with evaporation, because the temperature of ice formation is about seven times lower than the vaporization temperature, and the loss of dry matter is less than $1 \%$. So, the main stages of production were baking the milk, its fermentation and cryo-concentration. In the technology BK-Uglich-SMT (Lac. lactis subsp. lactis, 
Lac. lactis subsp. cremoris, Lac. lactis subsp. lactis biovar diacetilactis, Str. thermophilus) was used as a starter (100 g per $1000 \mathrm{~kg}$ of product).

The prebiotic component was added at the fermentation stage, thereby accelerating the fermentation process. The extruded chickpea flour was previously partially hydrated at $20^{\circ} \mathrm{C}$ for 30 minutes. The ratio of chickpea flour to water was 1:0.5. This ratio was determined by the fact that after self-pressing, i.e. thawing, the protein coagulum is extremely spreadable and had a slightly watery consistency; therefore, partially hydrated flour added at the stage of the setting of blend improved the structure of the protein coagulum, making it more dense and homogeneous.

The formulation characteristics of the samples produced were the following: control sample was without fillers; test sample 1 contained $3 \%$ of chickpea flour; test sample 2 contained $6 \%$ of chickpea flour $+1.5 \%$ Laktusan; and test sample 3 contained $6 \%$ of chick-pea flour $+3 \%$ Laktusan.

\section{Analysis of the finished product characteristics}

The tasks of the experiment were to determine the organoleptic, physical-chemical, microbiological and rheological characteristics of the finished product. For these purposes, the standard and conventional techniques that satisfy the objectives of the study were used. Each measurement was performed in triplicate. The physical and chemical characteristics of the plant component were determined in accordance with the requirements of GOST 9404-88 "Flour and bran. Method of moisture content determination"; GOST 10846-91 "Grain and products of its processing. Method for determination of protein"; and GOST 32905-2014 (ISO 6492:1999) "Feeds, mixed feeds and raw material. Method for determination of fat content". The physical and chemical characteristics of the milk products developed were determined in accordance with the requirements of GOST R 55063-2012 "Kinds of cheese and processed cheese. The rules of test acceptance, sampling and control methods"; and GOST R 56415-2015 "Specialized milk-based products. Determination of selenium content". Sensory analysis of the developed milk products was carried out in accordance with GOST R ISO 22935-2-2011 "Milk and milk products. Sensory analysis. Part 2. Recommended methods for sensory evaluation" and GOST R ISO 22935-3-2011 "Milk and milk products. Sensory analysis. Part 3. Guidance on a method for evaluation of compliance with product specifications for sensory properties by scoring". The microbiological characteristics of the developed milk products were determined in accordance with the requirements of GOST 32901-2014 "Milk and milk products. Methods of microbiological analysis" and GOST 10444.11-2013 (ISO 15214:1998) "Microbiology of food and animal feeding stuffs. Methods for detection and enumeration of mesophilic lactic acid bacteria". The calculation of the energy value ( $\mathrm{kcal} / 100 \mathrm{~g}$ ) was carried out with account of the content of proteins, fats and carbohydrates in the final product according to the formula:

$$
E V=\sum \frac{\left(G_{i} \cdot m_{k i}\right)}{m_{D M i}} \cdot \frac{D M}{100},
$$

where $G_{i}$ - the weight fraction of proteins, fats and carbohydrates in the $i^{\text {th }}$ component of the formulation, \%;

$m_{k i}$ - the weight of the individual $i^{\text {th }}$ component that was used for the production of $100 \mathrm{~g}$ of product (consumption in kind according to the consolidated formulation), g;

$m_{D M i}$ - the weight of dry matter per $100 \mathrm{~g}$ of the $i^{\text {th }}$ component, g;

$D M$ - the weight of dry matter per $100 \mathrm{~g}$ of product (according to the consolidated formulation), $\mathrm{g}$.

The calculation of the nutritional value ( $\mathrm{g}$ per $100 \mathrm{~g}$ ) includes a number of proteins, fats and carbohydrates with respect to their digestibility coefficient and is calculated according to the formulas:

$$
P(D C)=\frac{\sum P \cdot 84.5}{100} ; F(D C)=\frac{\sum F \cdot 94}{100} ; \text { and } C(D C)=\frac{\sum C \cdot 95.6}{100},
$$

where $P(D C), F(D C)$ and $C(D C)$ - the proteins, fats and carbohydrates, respectively, with respect to their digestibility coefficient;

$\sum P, \Sigma F$ and $\Sigma C$ - the amounts of proteins, fats and carbohydrates of all the ingredients in the product. 


\section{Statistical data processing}

The experimental data were analyzed by the Statistica 10.0 package using conventional techniques. The threshold of 0.05 was considered a minimum threshold of the significance of differences [11]. The MS Office 2010 was used for graphical interpretation of the digital data.

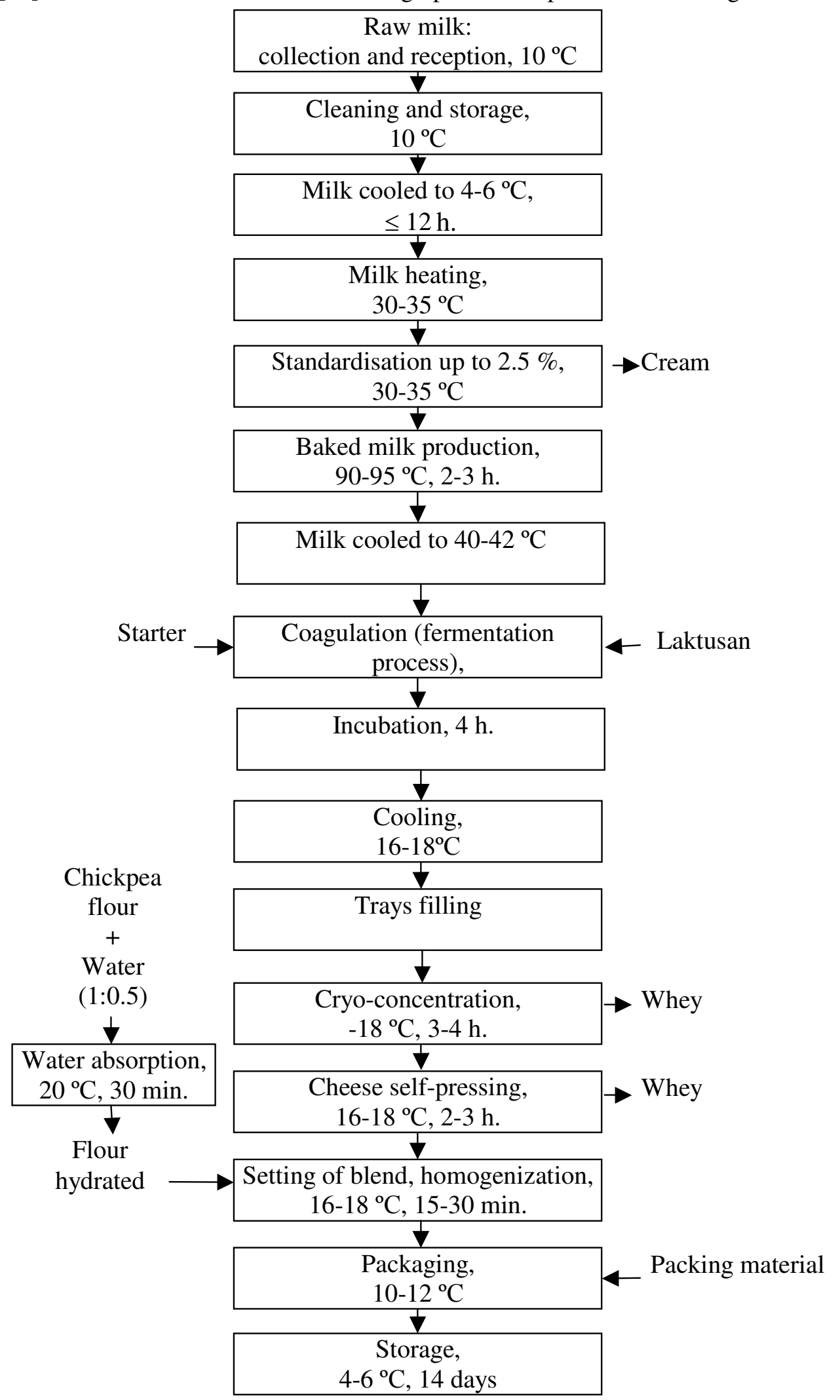

Fig. 2. Flow sheet of the cheese product production 


\section{Results and Discussion}

The wet-heat treatment of the raw material by extrusion effectively increased its nutritional value and digestibility (Table 1). Heating to higher temperatures caused dextrinization of starch, i.e. the formation of soluble carbohydrates and moisture in combination with high temperature promoted its gelatinization.

Chemical composition of chickpea

Table 1

\begin{tabular}{|c|c|c|}
\hline \multirow{2}{*}{ Parameters } & \multicolumn{2}{|c|}{ Content, \% of dry matter } \\
\cline { 2 - 3 } & Chickpea grain & Extruded chickpea \\
\hline Protein & $28.00 \pm 1.00$ & $35.02 \pm 1.22$ \\
\hline Fat & $5.50 \pm 0.50$ & $3.02 \pm 0.22$ \\
\hline Carbohydrates, & $59.50 \pm 1.70$ & $50.52 \pm 1.52$ \\
incl. starch & $48.00 \pm 1.40$ & $34.02 \pm 0.82$ \\
\hline Stachyose & $2.50 \pm 0.06$ & $1.52 \pm 0.05$ \\
\hline Verbascose & $4.10 \pm 0.07$ & $2.48 \pm 0.07$ \\
\hline Raffinose & $1.00 \pm 0.02$ & $0.60 \pm 0.03$ \\
\hline
\end{tabular}

An important feature of the extruded chickpea is its hydrophilicity. When immersed in water, the product treated considerably increases its volume compared to the state before the treatment. The swelling rate had its pronounced maximum, and intense swelling occurred for the first 10 minutes. This feature was useful for thickening that determined the application perspectiveness of the extruded chickpea flour as a stabilizer. The extrusion processing improved the digestibility of proteins, made the amino acids more accessible that resulted from the destruction of the secondary bonds protein in the molecules. Due to the relatively low temperatures and short duration of the heat treatment, the amino acids themselves were not destroyed. At the same time, the extrusion neutralized the factors that adversely affected the nutritional value of the raw material, such as an inhibitor of trypsin, urease and others. At the end of the processing, the temperature and pressure in the extruder came down with a run, resulting in an increase in the volume of the final product. A rupture of the walls of fat cells occurred, thereby the energy value of the product increased. The fat stability increased, because the enzymes such as lipase, causing rancidity of oils, were destroyed during the extrusion, and the lecithin and tocopherols, which were natural stabilizers, retained total activity.

Table 2 shows the values of the parameters characterizing the structural and mechanical properties of the resulting extruded chickpea.

Structural and mechanical parameters of extruded chickpea quality

\begin{tabular}{|c|c|}
\hline Parameter & Value \\
\hline Bulk weight, $\mathrm{kg} \cdot \mathrm{m}^{-3}$ & 434.9 \\
\hline Swelling ability, $\mathrm{cm}^{3} \cdot \mathrm{g}^{-1}$ & 9.02 \\
\hline Moisture retaining capacity, $\%$ & 5.02 \\
\hline Rupture coefficient & 2.22 \\
\hline
\end{tabular}

Sensory evaluation of the milk products developed was conducted in the laboratory. The characteristics like appearance, consistency, taste, flavor and color were evaluated. The organoleptic characteristics of the samples produced are shown in Table 3.

According to the data given in the table, a diagram of the organoleptic characteristics, which is presented in Figure 3, was built.

The analysis showed that the control sample differs from the test samples in several characteristics. The test samples 1,2, and 3 were similar in appearance, texture and consistency, but differed in taste, flavor and color. The test samples 1 and 2 had a slight taste of "popcorn" and the test sample 3 was further characterized by a taste of lactulose. The control sample had the flavor of baked milk, while the test samples 1 and 2 further had a slight flavor of "popcorn" and the test sample 3 had a delicate aroma of lactulose. The colors of the control sample, the test samples 1 and 2 were similar; 
the test sample 3 had a brighter color. Thus, it may be concluded that the formulation of thee test sample 3 was optimal because of a more pronounced taste and flavor, typical for a cheese product.

Table 3

Organoleptic characteristics of the samples produced

\begin{tabular}{|c|c|c|c|c|c|}
\hline \multirow[b]{2}{*}{$\begin{array}{c}\text { Item } \\
\text { description }\end{array}$} & \multicolumn{5}{|c|}{ Characteristics } \\
\hline & Appearance & $\begin{array}{c}\text { Consistency/ } \\
\text { texture }\end{array}$ & Taste & Flavor & Colour \\
\hline Control & $\begin{array}{c}\text { surface is } \\
\text { homoge-neous, } \\
\text { spreadable }\end{array}$ & $\begin{array}{l}\text { homoge-neous, } \\
\text { delicate, creamy }\end{array}$ & $\begin{array}{c}\text { delicate, taste of } \\
\text { sour milk with a } \\
\text { slight flavor of } \\
\text { baked milk }\end{array}$ & $\begin{array}{l}\text { clear, aroma of } \\
\text { sour milk with a } \\
\text { slight flavor of } \\
\text { baked milk }\end{array}$ & cream-white \\
\hline Sample 1 & $\begin{array}{c}\text { surface is } \\
\text { spreadable with } \\
\text { the presence of } \\
\text { flour grains }\end{array}$ & $\begin{array}{c}\text { delicate, creamy } \\
\text { with the } \\
\text { presence of flour } \\
\text { grains }\end{array}$ & $\begin{array}{c}\text { delicate, taste of } \\
\text { sour milk with a } \\
\text { slight flavor of } \\
\text { chickpea }\end{array}$ & $\begin{array}{l}\text { clear, aroma of } \\
\text { sour milk with a } \\
\text { slight flavor of } \\
\text { chickpea flour }\end{array}$ & $\begin{array}{c}\text { cream-white } \\
\text { with visible } \\
\text { particles of } \\
\text { flour }\end{array}$ \\
\hline Sample 2 & $\begin{array}{l}\text { surface is } \\
\text { spreadable with } \\
\text { the presence of } \\
\text { flour grains }\end{array}$ & $\begin{array}{c}\text { delicate, creamy } \\
\text { with the } \\
\text { presence of flour } \\
\text { grains }\end{array}$ & $\begin{array}{c}\text { delicate, taste of } \\
\text { sour milk with a } \\
\text { slight flavor of } \\
\text { chickpea and } \\
\text { honey } \\
\end{array}$ & $\begin{array}{l}\text { clear, aroma of } \\
\text { sour milk with a } \\
\text { slight flavor of } \\
\text { chickpea flour } \\
\text { and honey }\end{array}$ & $\begin{array}{l}\text { cream-white } \\
\text { with visible } \\
\text { particles of } \\
\text { flour }\end{array}$ \\
\hline Sample 3 & $\begin{array}{l}\text { surface is } \\
\text { spreadable with } \\
\text { the presence of } \\
\text { flour grains }\end{array}$ & $\begin{array}{c}\text { delicate, creamy } \\
\text { with the } \\
\text { presence of flour } \\
\text { grains }\end{array}$ & $\begin{array}{c}\text { delicate, taste of } \\
\text { sour milk with a } \\
\text { slight flavor of } \\
\text { honey }\end{array}$ & $\begin{array}{c}\text { clear, aroma of } \\
\text { sour milk with a } \\
\text { slight flavor of } \\
\text { honey }\end{array}$ & $\begin{array}{c}\text { cream-white } \\
\text { with visible } \\
\text { particles of } \\
\text { flour }\end{array}$ \\
\hline
\end{tabular}

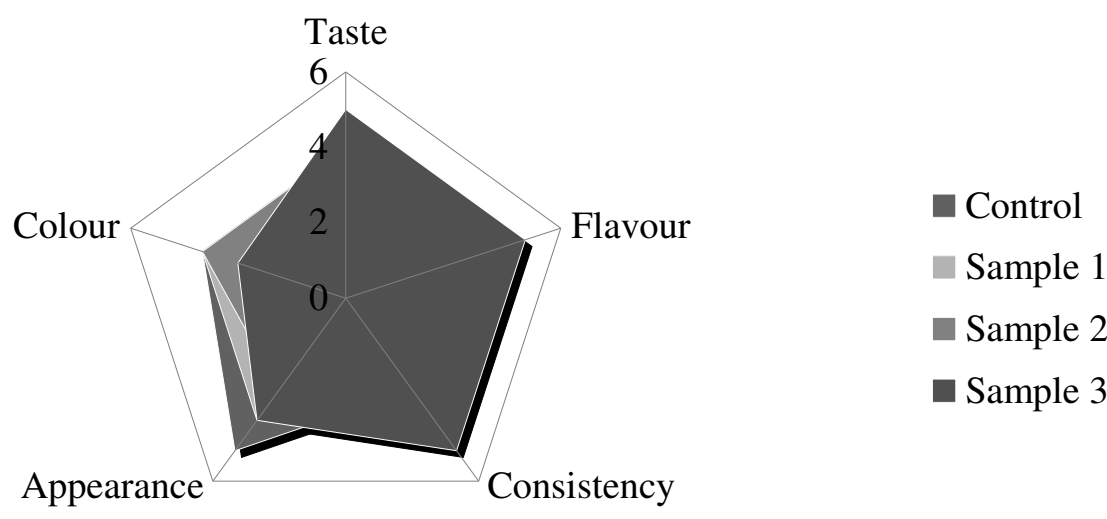

Fig. 3. Organoleptic characteristics

The results of the study of the protein content in the samples developed are shown in Figure 4.

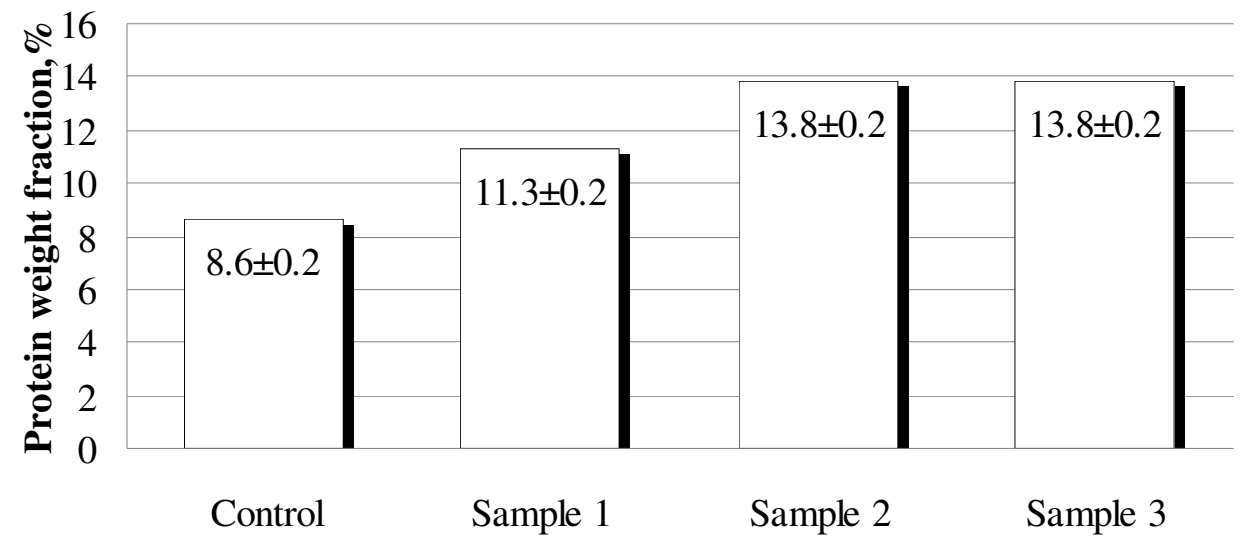

Fig. 4. Protein weight fraction 
This analysis showed that the chick-pea flour added considerably increased the amount of protein in the product that had a positive effect on its nutritional and energy value. The weight fractions of protein in the test samples 2 and 3 were higher by $5.2 \%$ compared to the control sample. Thus, the formulations of the test samples 2 and 3 were optimal with respect to the protein content in the final product. Adding of the plant and prebiotic components to the formulation made it possible to increase the dry matter content of the final product. The weight fractions of dry matter in the samples are shown in Figure 5.

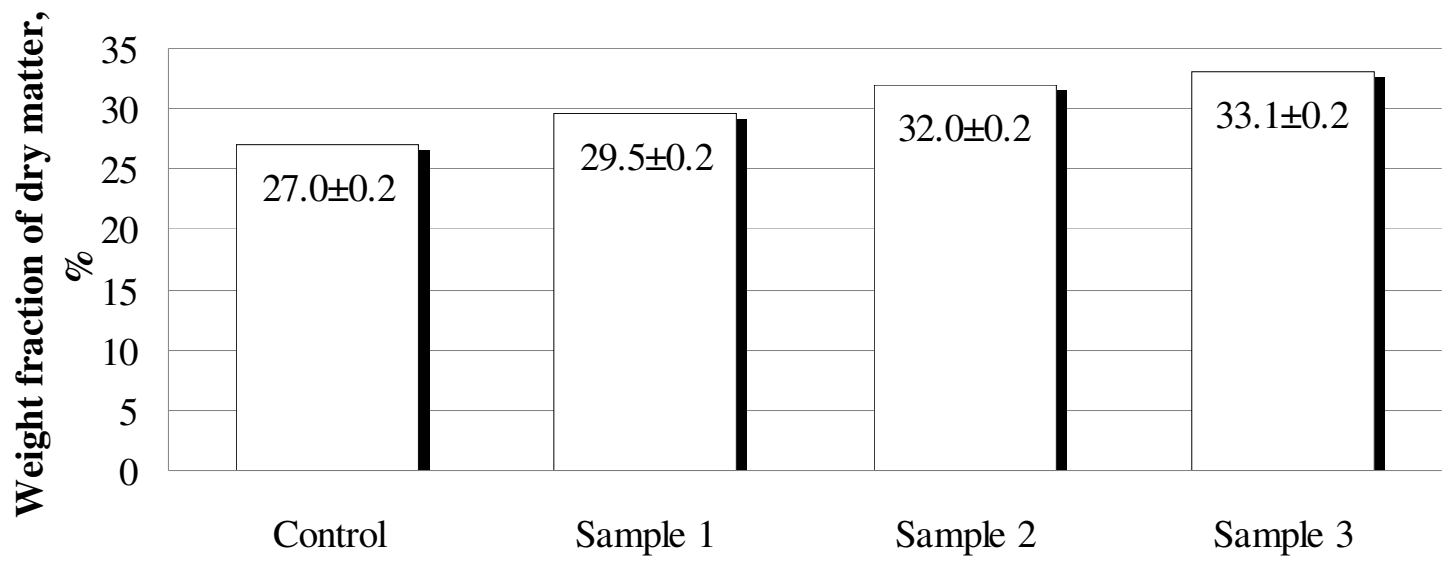

Fig. 5. Weight fractions of dry matter

The weight fractions of selenium in the samples are shown in Figure 6.

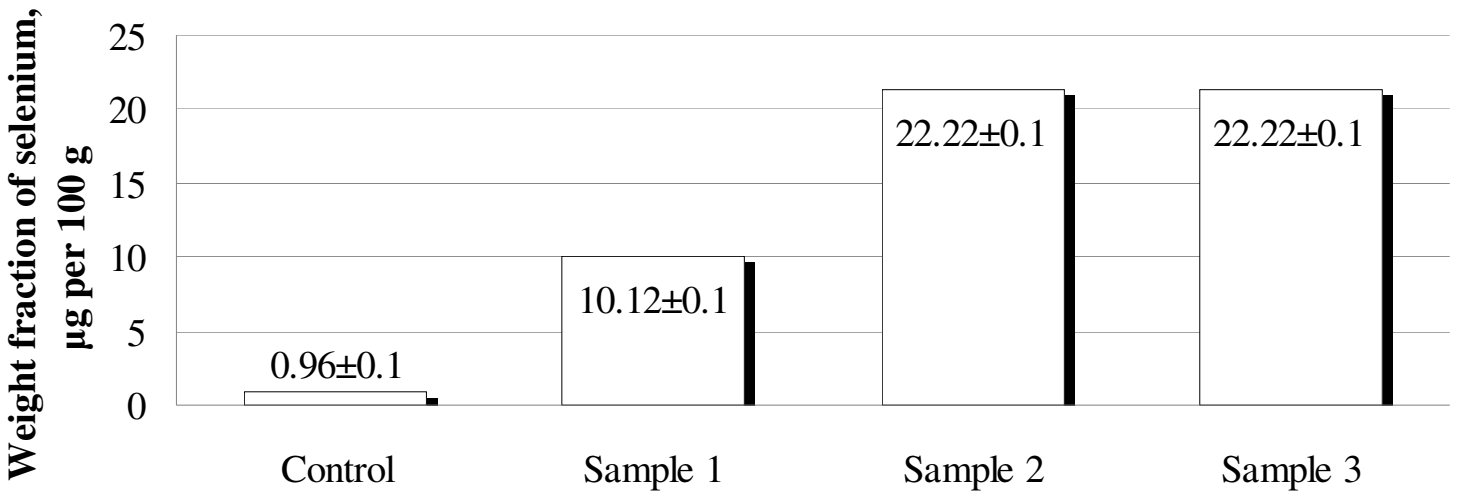

Fig. 6. Weight fractions of selenium

The analysis showed that the $3 \%$ chick-pea flour added increased the weight fraction of selenium by $10.1 \mathrm{mcg}$, while $6 \%$ chick-pea flour by $22.5 \mathrm{mcg}$, that was $28 \%$ of the daily intake of selenium.

The effect of lactulose on the change of titratable acidity during fermentation of the samples is shown in Figure 7.

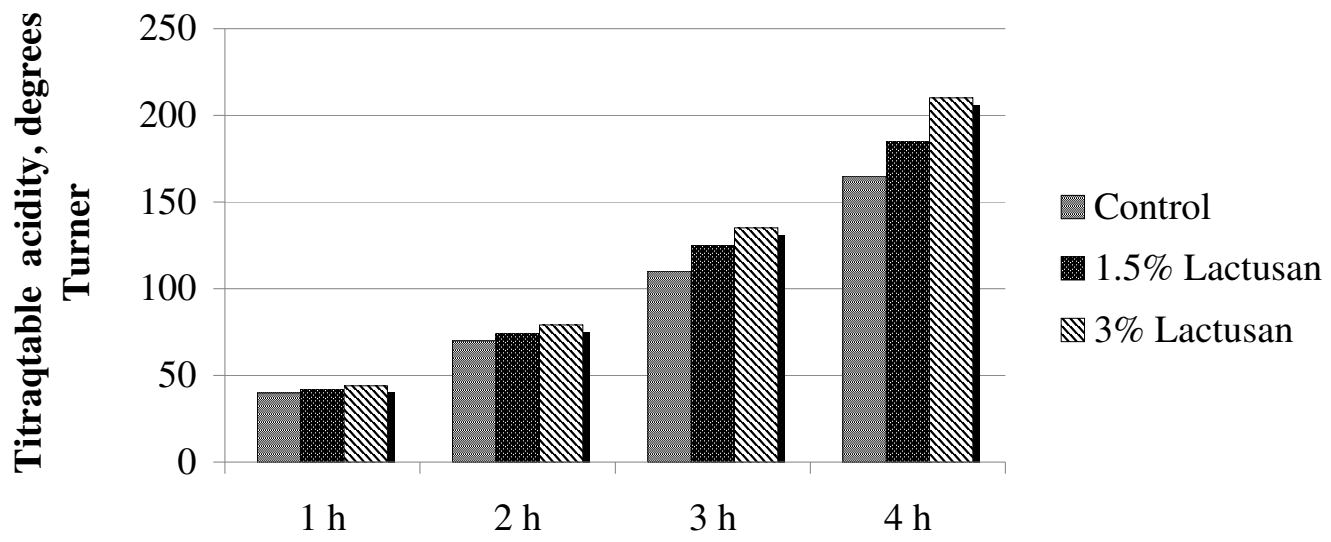

Fig. 7. Effect of lactulose on the fermentation process 
The analysis of the data shows that the lactulose added did not have a significant effect on the initial acidity of the mixture. In 2 hours of the fermentation process the sample with $3 \%$ lactulose syrup was registered to have a higher titratable acidity than the control sample. Further, all the test samples were registered to have more active acid production. So, in 3 hours of fermentation of the mixture in the $1.5 \%$ lactulose sample, the titratable acidity was by $12 \%$ and in the $3 \%$ lactulose sample by $21 \%$ higher than in the control sample. So, adding of lactulose increased the fermentation process.

The calculated indices of nutritional and energy values of the sample selected are presented in Table 4.

Table 4

Indices of food and energy value

\begin{tabular}{|c|c|c|c|}
\hline Sample & Energy values, kcal per 100 g & \multicolumn{2}{|c|}{ Nutritional values, $\mathbf{g}$ per 100 g of a product } \\
\hline \multirow{3}{*}{ Control } & \multirow{2}{*}{110.02} & Proteins & 8.6 \\
\cline { 3 - 4 } & & Fats & 4.68 \\
\cline { 3 - 4 } & & Carbohydrates & 8.4 \\
\hline \multirow{3}{*}{ Sample 1 } & \multirow{2}{*}{127.78} & Proteins & 11.3 \\
\cline { 3 - 4 } & & Fats & 4.74 \\
\cline { 3 - 4 } & & Carbohydrates & 9.98 \\
\hline \multirow{2}{*}{ Sample 2 } & \multirow{2}{*}{150.82} & Proteins & 13.8 \\
\cline { 3 - 4 } & & Fats & 4.98 \\
\cline { 3 - 4 } & & Carbohydrates & 12.7 (incl. lactulose 1.5) \\
\hline \multirow{2}{*}{ Sample 3 } & \multirow{2}{*}{157.45} & Proteins & 13.8 \\
\cline { 3 - 4 } & & Fats & 5.02 \\
\cline { 3 - 4 } & & Carbohydrates & 14.2 (incl. lactulose 3.0) \\
\hline
\end{tabular}

As it is clear from the table, the prebiotic and vegetable components added increased the nutritional and energy contents of the cheese product. At the same time, due to the reduced content of fat it was considered a dietary low-caloric product.

\section{Conclusions}

Adding of extruded chick-pea flour to the formulation of the cheese product contributes to the improvement of consumer-oriented characteristics and the combination with the lactulose prebiotics causes its functional properties.

\section{References}

1. Belik S.N., Gorlov I.F., Slozhenkina M.I. etc. Morpho-functional state of the liver of the rats fed the rations with meat of the pigs grown with antimicrobials. Pakistan Veterinary Journal, 2015, vol. 35 (3), pp. 325-328.

2. Gorlov I.F., Levakhin V.I., Azhmuldinov E.A. etc. Method for producing environmentally safe meat in radioactively contaminated area. Asian Journal of Animal Sciences, 2015, vol. 10 (1), pp. 99-105.

3. Gorlov I., Poznyakovskiy V., Shelepov V., Tikhonov S. About the quality of meat with PSE and DFD properties. Foods and Raw Materials, 2015, vol. 3 (1), pp. 104-110.

4. Montel M.-C., Buchin S., Mallet A. etc. Traditional cheeses: Rich and diverse microbiota with associated benefits. International Journal of Food Microbiology, 2014, vol. 177, pp. 136-154.

5. Bachmann H.-P. Cheese analogues: a review. International Dairy Journal, 2001, vol. 11 (4-7), pp. 505-515.

6. Gorlov I.F., Gelunova O.B., Giro, T.M., Mirzayanova E.P. The usage of animal and vegetable origin raw materials combinatorics in meat products of "halal" category development. American Journal of Agricultural and Biological Science, 2014, vol. 9 (4), pp. 474-481.

7. Gorlov I.F., Slozhenkina M.I., Karpenko E.V. etc. Effect of a new low-cholesterol meat and vegetal product on correction of simulated lipid metabolism disorders in rats. Voprosy Pitaniia, 2015, vol. 84 (1), pp. 80-88. 
8. Gorlov I.F., Giro T.M., Sitnikova O.I. etc. New functional products with chickpeas: Reception, functional properties. American Journal of Food Technology, 2016, vol. 11 (6), pp. 273-281.

9. Chechetkina A., Iakovchenko N., Zabodalova, L. The technology of soft cheese with a vegetable component. Agronomy Research, 2016, vol. 14 (5), pp. 1562-1572.

10. Sabel'nikova E A. Clinical aspects of intestinal dysbacteriosis. Eksperimental'naià i klinicheskaia gastroenterologiiā (Experimental \& clinical gastroenterology), 2011, vol. 3, pp. 111-116.

11. Johnson R.A., Bhattacharyya G.K. Statistics principles and methods. Sixth edition. USA: John Wiley \& Sons, 2010. 706 p. 